\title{
Metallurgical Characterization of a Weld Bead Coating Applied by the PTA Process on the D2 Tool Steel
}

\author{
Ali Tahaei ${ }^{1}$, Felipe Garcia Vazquez ${ }^{2}$, Mattia Merlin ${ }^{1}$, Ana Arizmendi-Morquecho ${ }^{3}$, Felipe Arturo Reyes Valdes ${ }^{2}$, \\ Gian Luca Garagnani ${ }^{1}$ \\ 1 Università di Ferrara, Dipartimento di Ingegneria (ENDIF), Ferrara, Italia. \\ 2 Corporación Mexicana de Investigación en Materiales (Comimsa), Saltillo, Mexico. \\ 3 Centro de Investigacion en Materiales Avanzados (Cimav) - Unidad Monterrey, Nuevo León, Mexico.
}

Received: 26 Jan., 2016

Accepted: 10 June, 2016

E-mail: ali.tahaei@unife.it (AT)

\begin{abstract}
In this investigation, a nickel-base powder mixed with tungsten carbide particles was applied by Plasma Transferred Arc welding (PTA) on the surface of the D2 cold work tool steel to improve surface quality and to extend its lifetime during applications. The Design of Experiment (DoE) method was applied to obtain the appropriate combination of hardfacing parameters and to run the minimum number of tests. Current, travel speed and preheat were considered as variable parameters. These parameters are important to reach a final layer with an appropriate bead geometry accompanied with good metallurgical properties. All samples were prepared for metallurgical investigations and the effect of process parameters on the weld bead geometry was considered. For each experiment run, weld bead geometry parameters were measured including dilution, penetration and reinforcement. Microstructures and the distribution of tungsten carbide particles after welding were analyzed by Optical Microscopy (OM) and Scanning Electron Microscopy (SEM) equipped with an EDS microprobe. In addition, hardness tests were performed to evaluate the mechanical properties of the weld bead layers. Finally, among all the experiments, the best sample with appropriate bead geometry and microstructure was selected.
\end{abstract}

Key-words: Design of Experiment (DoE); Hardfacing; Nickel-base powder; PTA process; Tool steel.

\section{Caracterização Metalúrgica de um Revestimento de Cordão de Solda Aplicado pelo Processo de PTA no Aço Ferramenta D2}

Resumo: Nesta investigação, uma mistura de pó a base de níquel com partículas de carboneto de tungstênio foi aplicada por Soldagem a Plasma com Arco Transferido (PTA), na superfície de um aço ferramenta trabalhado a frio D2, para melhorar a qualidade superficial e ampliar o tempo de vida durante as aplicações. Para obter a combinação de parâmetros de aplicação do revestimento apropriada e para executar um número mínimo de testes, foi aplicado o método de Desenho de Experimentos (DoE). Corrente, velocidade de soldagem e pré-aquecimento foram considerados como parâmetros variáveis. Estes parâmetros são importantes para alcançar uma camada final com uma geometria do cordão adequada acompanhada por boas propriedades metalúrgicas. Todas as amostras foram preparadas para investigações metalúrgicas e o efeito dos parâmetros de processo sobre a geometria do cordão de solda foi considerado. Para cada experimento, foram medidos as dimensões da geometria do cordão de solda, incluindo a diluição, penetração e reforço. Microestruturas e a distribuição das partículas de carboneto de tungstênio após a soldagem foram analisadas por Microscopia Óptica (MO) e Microscopia Eletrônica de Varredura equipada com microssonda EDS. Além disso, ensaios de microdureza foram realizados para avaliar as propriedades mecânicas (MEV) das camadas de cordões de solda. Finalmente, entre todos os experimentos, a melhor amostra com microestrutura e geometria do cordão adequada foi selecionada.

Palavras-chave: Projeto de experimento; Revestimento duro; Pó de níquel; Processo di PTA; Aços ferramenta.

\section{Introduction}

The surface hardening processes can improve tribological, wear and corrosion properties of industrial components working in harsh situations [1-3]. Among different welding processes, Plasma Transferred Arc (PTA) is a relatively new method compared to other conventional welding processes such as GTAW and GMAW [3]. In the PTA method,
This is an Open Access article distributed under the terms of
the Creative Commons Attribution Non-Commercial License which permits unrestricted non-commercial use, distribution, and reproduction in any medium provided the original work is properly cited. 
the filler material in the form of powders is carried from the powder holder to the weld pool [4]. By means of this method, layers with different thicknesses and a strong metallurgical bond to the substrate can be produced. In addition, it has high productivity and ability to automation for weld overlay applications [1,5]. In addition, in the PTA method, the value of dilution can be kept at a minimum, and by adjusting the feeding rate a sound weld bead is achievable [3,6]. The impact of the PTA process parameters on the microstructure and properties of the weld bead has been investigated by many researchers [7-9]. Boulithis et al. [7] studied the effect of PTA surface treatments on tool steel before and after applying heat treatment. Nouri et al. [10] worked on the effect of the welding parameters on the properties of the hardface layer.

Chatterjee and Pal [11] worked on the deposition of various layers, considering the change of welding parameters such as current and travel speed. Other authors [12-14] found that different values of these parameters cause the change in the heat input and in the dilution as a consequence. Moreover, their studies demonstrated that nickel-base powders used as hardfacing material can also improve the corrosion resistance of a steel product. For improving the wear resistance properties of the substrate, tungsten carbides (WC) can be usefully added to the nickel-base powders. After the deposition of the powders, the nickel matrix acts as a binder for the tungsten carbide particles. Carbides of different elements, such as tungsten, vanadium, chromium and titanium, can be mixed in different proportions to nickel-base powders and be applied on a steel product to improve its surface properties [15]. Balamurugan and Murugan [16] studied the optimization of the PTA process for weld overlays reinforced by TiC particles. It should be mentioned that several parameters in the PTA process, such as current, feeding rate and travel speed, have a direct effect on surface quality $[17,18]$.

Weld bead is an important geometric parameter able to define the properties of the hardfaced layer: several studies demonstrated that there is a close relation between the weld bead shape and the quality of the layer [19-21]. Considering the different type of equipment, powder mixtures and process parameters, many combinations of the specifications could be used to find an appropriate welding procedure. To minimize this combination of parameters, it would be useful to use the Design of Experiment (DoE) method. As a result, it is possible to decrease the number of test runs, to obtain an appropriate weld bead [16]. The effect of the feeding rate and travel speed on the quality of a nickel-based hardfacing layer applied on low carbon steels was reported by Ming et al. [22] and Lim et al. [23]. Palani and Murugan $[24,25]$ investigated the optimization of parameters for the weld overlay of stainless steel on carbon steel. Davis [16] tried to find appropriate dilution and weld bead geometry by changing the process parameters. Siva et al. [26] worked on the optimization of the PTA process by using nickel-base powders on stainless steel. Despite many investigations, there is still a lack of information regarding the optimization of the welding conditions to obtain appropriate weld bead geometries accompanied with high mechanical and metallurgical properties. The aim of this study was to identify the best parameters (current, travel speed and preheat) to reach the appropriate hardfaced layer of nickel base powder mixed with tungsten carbide on the D2 tool steel using the PTA process. Based on the DoE method, twenty weld overlays with different parameters were performed on the surface of tool steel. The microstructural properties of each layer were evaluated by means of Optical Microscopy (OM) and Scanning Electron Microscopy (SEM) with Energy Dispersive Spectroscopy (EDS). The mechanical properties were studied by means of hardness tests. Finally, based on the metallurgical features and the weld bead geometry measurements of the layers, the best-investigated process parameters were detected.

\section{Materials and Experimental Procedure}

\subsection{Materials}

In this study, the Plasma Transferred Arc (PTA) welding process was used to apply a hardfacing layer nickel base powder on the D2 tool steel. The tool steel in the form of a plate-like block with dimensions of $130 \mathrm{~mm} \times 50 \mathrm{~mm} \times 12.5 \mathrm{~mm}$ was selected as a substrate. In Table 1, the chemical composition of the D2 steel is specified. Before applying the hardfacing layer to the steel substrate, according to Chandler [27] a specific heat treatment was performed on three blocks in order to reach appropriate hardness and toughness. In particular, the blocks were preheated at $790^{\circ} \mathrm{C}$ for 1 hour, then the temperature was increased to $1100^{\circ} \mathrm{C}$ and maintained for $35 \mathrm{~min}$. The blocks were then quenched in an oil bath and subjected to two subsequent steps of tempering at $315^{\circ} \mathrm{C}$ for 2 hours. After the heat treatment, oxides and possible contaminants were removed from the surfaces. A mixture with $40 \%$ by weight of spherical nickel-base powders and $60 \%$ of agglomerated WC particles was selected as the hardfacing material in this investigation. The morphology of the nickel-base powders is shown in Figure 1. In Table 2, the nominal chemical compositions of both the nickel-base powders and the WC reinforcing material are reported. 
Table 1. Chemical composition (wt\%) of the base metal.

\begin{tabular}{ccccccccccc}
\hline & \multicolumn{10}{c}{ Elements } \\
\cline { 2 - 14 } & $\mathbf{C}$ & Si & Mn & Cr & Mo & V & P & S & Fe \\
D2 tool steel & 1.58 & 0.37 & 0.48 & 11.52 & 0.89 & 0.56 & 0.017 & 0.029 & Bal. \\
\hline
\end{tabular}

Table 2. Chemical composition (wt\%) of the powder.

\begin{tabular}{lccccccc}
\hline & \multicolumn{9}{c}{ Elements } \\
\cline { 3 - 8 } & & C & Si & Cr & B & W & Ni \\
Hardfacing & Matrix & $0.6-0.8$ & $3.9-4.9$ & $14.0-16.0$ & $3.0-3.4$ & - & Bal. \\
powder alloy & Reinforcement & $6.0-6.2$ & - & - & - & Bal. & - \\
\hline
\end{tabular}

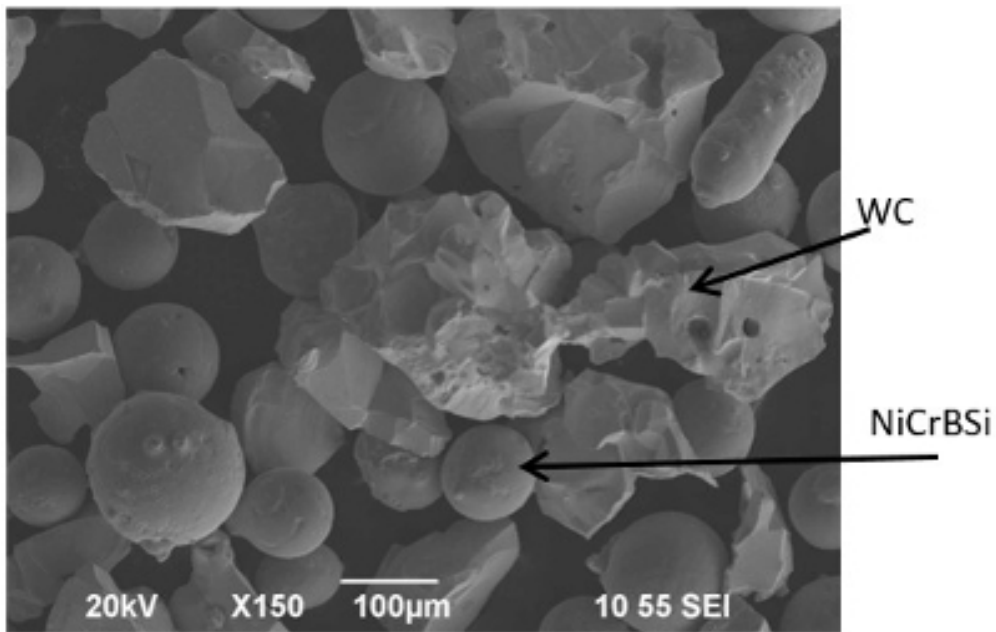

Figure 1. Morphology of the nickel-base powder mixed with WC particles.

\subsection{PTA equipment and process design}

In this investigation, the plasma machine with the Castolin Eutectic Eutronic Gap 3001DC trademark was used to apply the hardfacing layer on the tool steel. In the PTA process, several working parameters had to be carefully adjusted. Some of these parameters were considered as fixed and they are reported in Table 3, while current $(\mathrm{I})$, preheat $(\mathrm{T})$ and travel speed $(\mathrm{S})$ were considered as variable. In particular, preheat was identified as a variable parameter due to the susceptibility of the D2 tool steel to crack initiation during welding. Based on the results obtained by applying the DoE method, considering three levels and five factors and the details of which will be presented by the authors in another paper, twenty layers were performed. Table 4 collects the combinations of variable parameters used in this investigation.

Table 3. Constant parameters of the PTA process.

\begin{tabular}{lc}
\hline$\quad$ Parameter & Value \\
Voltage $(\mathrm{V})$ & 20 \\
Nozzle diameter $(\mathrm{mm})$ & 3.2 \\
Torch to work piece distance $(\mathrm{mm})$ & 10 \\
Plasma gas $\mathrm{Ar}(\mathrm{l} / \mathrm{min})$ & 12 \\
Shielding gas $\mathrm{Ar}+10 \% \mathrm{H} 2(\mathrm{l} / \mathrm{min})$ & 3.5 \\
Carrier gas $(\mathrm{l} / \mathrm{min})$ & 3.5 \\
Feeding rate $(\mathrm{g} / \mathrm{min})$ & 29 \\
\hline
\end{tabular}


Table 4. Variable parameters considered in this investigation.

\begin{tabular}{lcccccc}
\hline & & \multicolumn{5}{c}{ Factor levels } \\
\cline { 3 - 7 } \multicolumn{1}{r}{ Parameter } & Notation & $\mathbf{- 1 . 6 8 2}$ & $\mathbf{- 1}$ & $\mathbf{0}$ & $\mathbf{+ 1}$ & $\mathbf{+ 1 . 6 8 2}$ \\
Current $(\mathrm{A})$ & & 86.36 & 100 & 120 & 140 & 153.63 \\
Preheat $\left({ }^{\circ} \mathrm{C}\right)$ & $\mathrm{T}$ & 181.82 & 250 & 350 & 450 & 518.18 \\
Travel speed & $\mathrm{T}$ & 59.7 & 70 & 85 & 100 & 110.2 \\
$(\mathrm{~cm} / \mathrm{min})$ & $\mathrm{S}$ & & & & \\
\hline
\end{tabular}

\subsection{Sample preparation and investigation}

Before starting any metallurgical analysis, liquid penetrant non-destructive testing was performed on the layers in order to verify the absence of any surface defect. Twenty sample cross-sections (from W1 to W20) were then cut, one from each layer, embedded in a thermoset resin and prepared with standard metallographic procedures. An Olympus SZX AO stereomicroscope equipped with Infinity analyze software was used for the measurements of the geometrical features of each weld layer. The schematic shape of the weld bead with indication of the most important geometrical parameters is shown in Figure 2. The values of reinforcement, penetration, weld bead and dilution were measured. Microstructural analysis was carried out on both the tool steel base metal and the weld overlay, after chemical etching in a $2 \%$ solution of $\mathrm{HNO}_{3}$ in ethylic alcohol (Nital 2) and in a solution of $30 \% \mathrm{HF}$ and $70 \% \mathrm{HNO}_{3}$, respectively. A Leica MF4M Optical Microscope and Zeis EVO EMA 15 Scanning Electron Microscope equipped with an EDS analyzer were used. For the evaluation of the mechanical properties, hardness tests were performed on the cross sections of each joint using a Future Tech Vickers machine and a load of $1 \mathrm{~kg}$. Vickers hardness profiles were determined in order to evaluate the evolution of hardness from the base metal to the weld layer across the heat-affected zone.

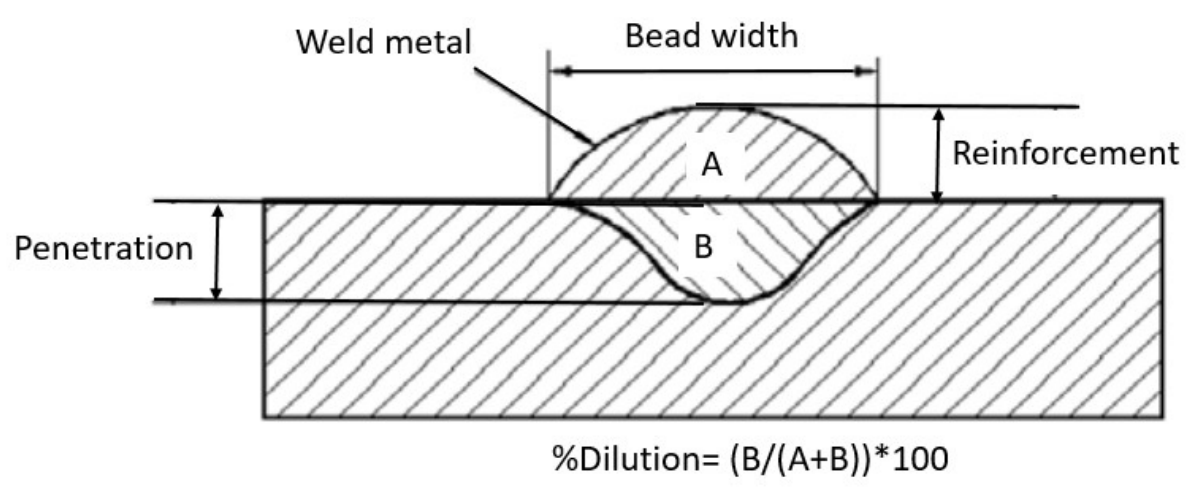

Figure 2. Weld bead geometry characteristics.

\section{Results and Discussion}

\subsection{Effect of process parameters on weld bead geometry}

According to the measurements performed on the sample cross-sections, Figure 3 describes the effect of the travel speed on penetration and dilution; in particular, when the travel speed is increased, the penetration decreases and, mainly with a travel speed of 85 and $100 \mathrm{~cm} / \mathrm{min}$, the minimum penetration values are obtained. The increase in the travel speed does not have a significant effect on dilution. When the travel speed is increased, the heat input and diffusion rate decrease; as a consequence, penetration decreases and reinforcement increases, thus keeping dilution relatively constant with just a smooth upward trend. The effect of the current on dilution and penetration is shown in Figure 4; when the current is increased, the values of penetration and dilution increase steeply, which is probably due to the increase in the heat input. 


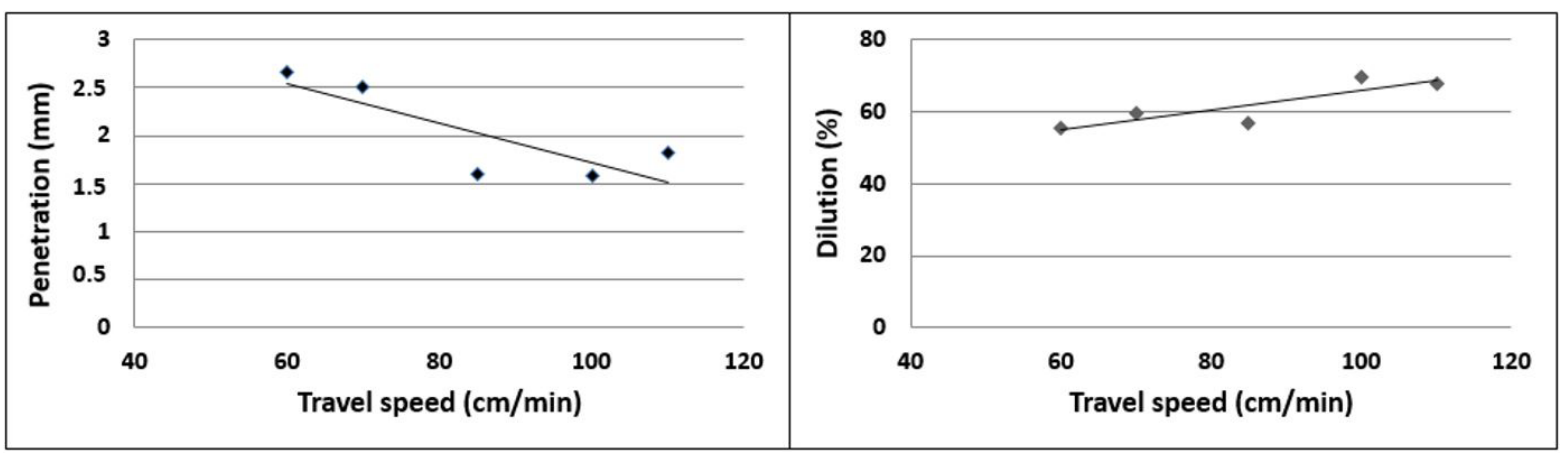

Figure 3. Effect of travel speed on penetration and dilution.

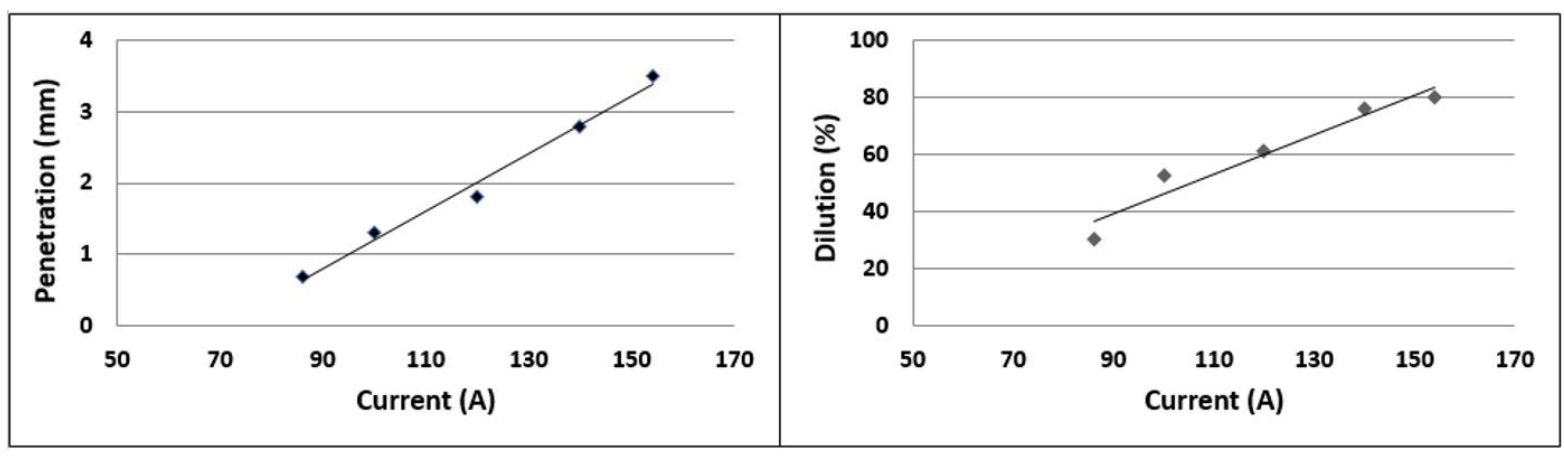

Figure 4. Effect of current on penetration and dilution.

\subsection{Microstructural characterization}

The low magnification structure of one sample cross-section observed at the stereomicroscope is reported in Figure 5a: the deposited layer, the heat affected zone and the base metal can be clearly identified. The presence of carbides in the tool steel and the dendritic structure in the deposits are visible at higher magnification in Figure $5 \mathrm{~b}$.
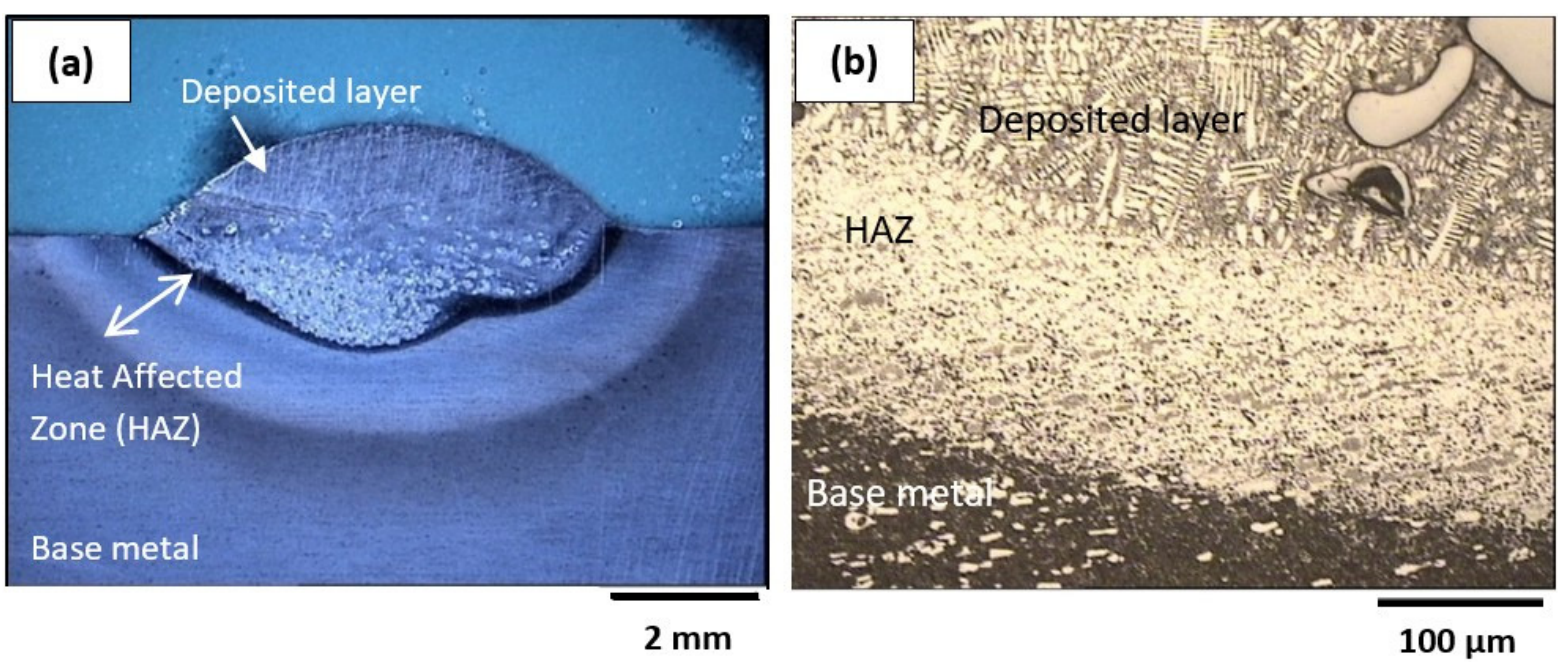

Figure 5. (a) Macrostructure of one weld overlay and (b) Microstructure of the three different zones. 
Figure 6 shows the cross-sections of some selected layers. As can be seen, sample W19 presents more regular weld bead geometry and a more homogenous distribution of tungsten carbides than the other samples. In sample W19 the tungsten carbide particles are better distributed through the whole area of the deposited layer. For most of the other samples, tungsten carbide particles are preferentially distributed at the bottom of the weld pool. Moreover, different samples present different values of penetration and reinforcement due to the different process parameters.

Figure 7 shows the microstructure of the $\mathrm{D} 2$ tool steel base metal, which mainly consists of $\mathrm{Cr}_{7} \mathrm{C}_{3}$ primary carbides and secondary carbides dispersed in a tempered martensitic matrix [28]. The heat affected zone (HAZ) is characterized by two different microstructures close to the fusion zone (Figure 8a) and close to the base metal (Figure 8b), respectively. The reason for the formation of these zones is probably due to the different heating and cooling rates during the hardfacing process. The typical microstructure of the nickel-based hardfacing layer
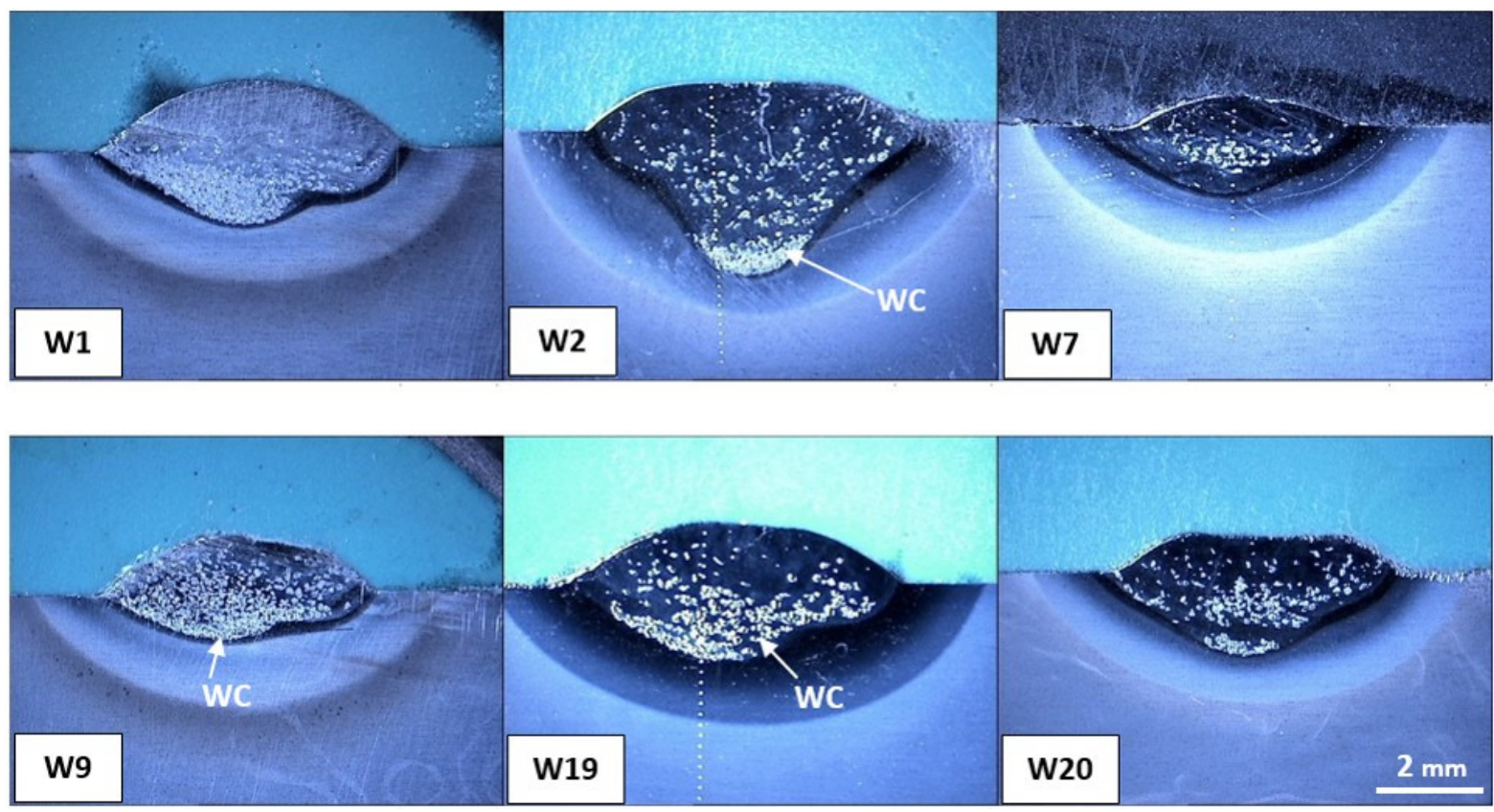

Figure 6. Weld bead shape of some selected samples.

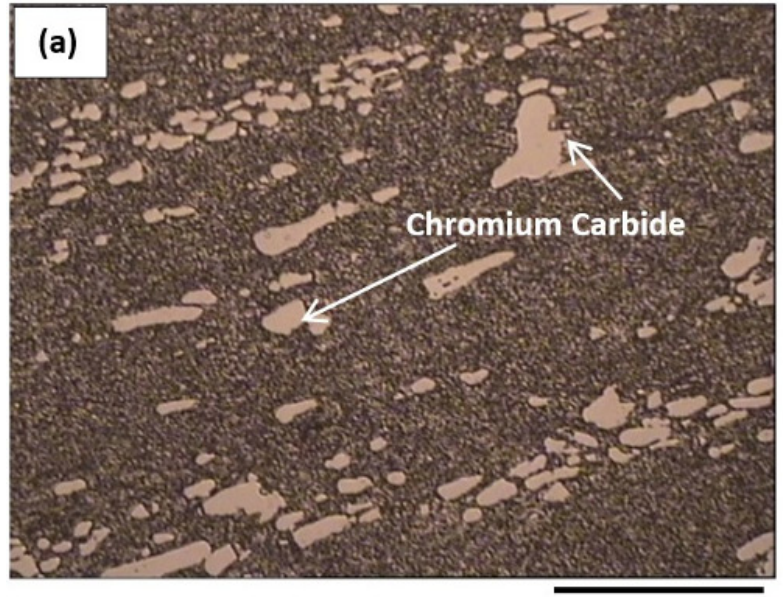

$50 \mu \mathrm{m}$

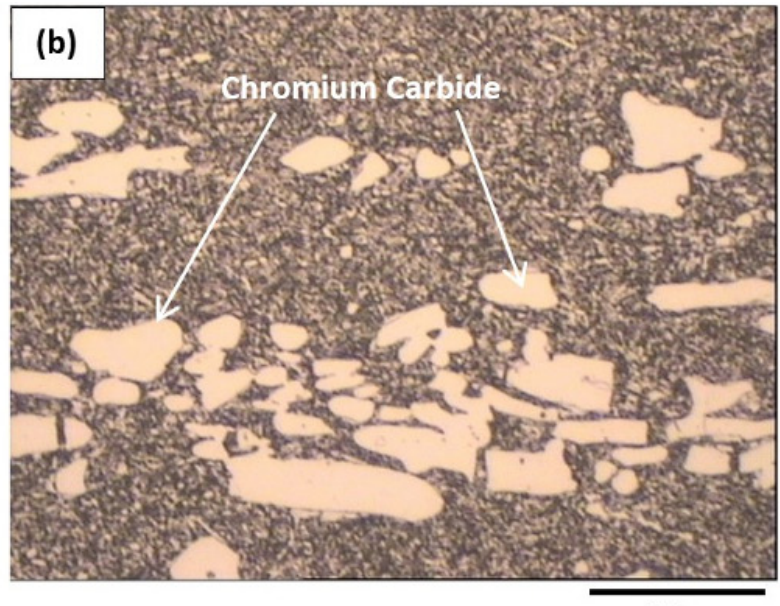

$20 \mu \mathrm{m}$

Figure 7. Microstructure of the base metal (a) 500X; and (b) 1000X. 
is shown in Figure 9 and is characterized by a $\mathrm{Y}$-Ni primary hypereutectic dendritic phase and a lamellar eutectic structure in the interdendritic regions [29]. Blocky-shaped tungsten carbide particles are distributed in the layer and are clearly visible in Figure 9a. Because of their high density, the volume fraction of tungsten carbides close to the top surface of the layer is lower than in the area at the bottom of the weld pool close to the substrate (Figure 10).

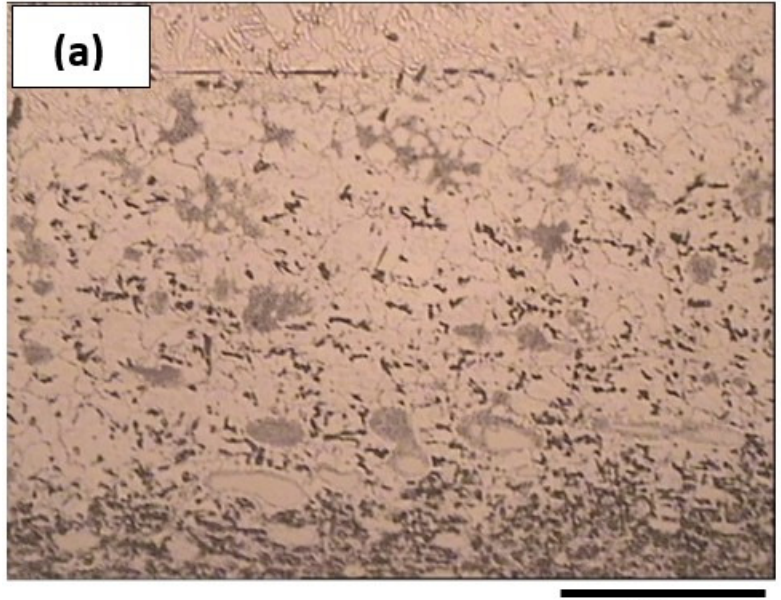

$50 \mu \mathrm{m}$

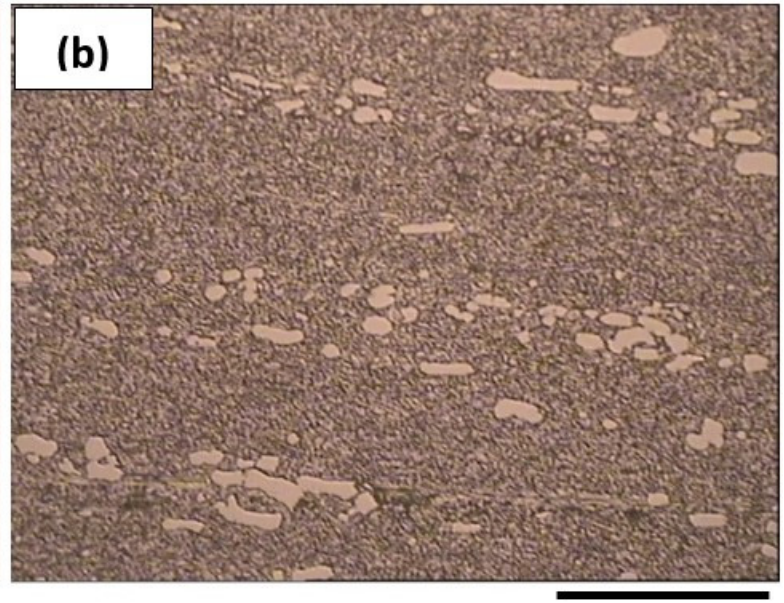

$50 \mu \mathrm{m}$

Figure 8. Microstructure of the heat affected zone (a) close to the fusion zone and (b) close to the base metal.
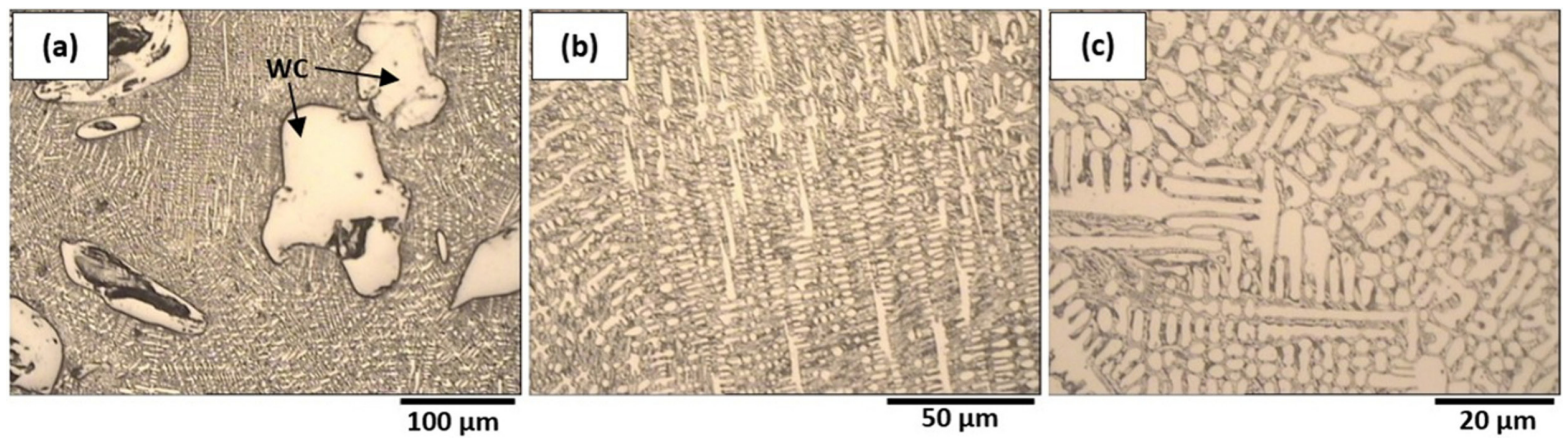

Figure 9. Microstructure of the weld overlay: (a) WC particles in the matrix; (b) and (c) dendritic matrix at different magnification.

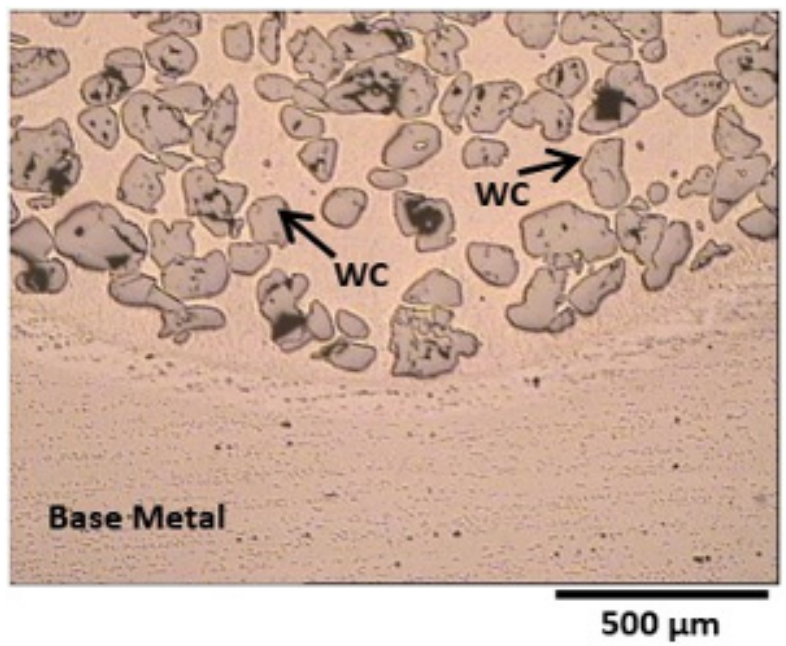

Figure 10. Distribution of WC particles at the bottom of the weld pool. 


\subsection{SEM and EDS analysis}

Back scattered images of the deposited layer, obtained by means of SEM from sample W1 are reported in Figure 11. To understand the distribution of alloying elements in the matrix, EDS analysis was performed on different positions and the results are collected in Table 5. In addition to large tungsten carbides, there are other different intermetallic phases containing nickel, chromium and silicon, distributed between the WC particles and matrix. The diffusion of interstitial carbon in the matrix is faster than other carbide former elements; in the presence of WC as a reinforced material, the formation of other complex and brittle carbides was reported in the literature [30].

EDS analysis of the carbides indicates that, in addition to existing chromium, which can precipitate as chromium carbide, there is also vanadium which is distributed in the matrix. From the results reported in Table 5, it can be observed that tungsten is also distributed in the matrix in the range between 15 to $22 \%$; spectrum 7 reveals a tungsten content of more than $50 \%$. This could be due to decarburization of $\mathrm{WC} / \mathrm{W}_{2} \mathrm{C}$ during the welding process; moreover, tungsten and carbon could be dissolved into the nickel and nickel-chromium phases. Dissolution of tungsten carbide particles in the matrix causes the precipitation of secondary carbides around the primary carbides.
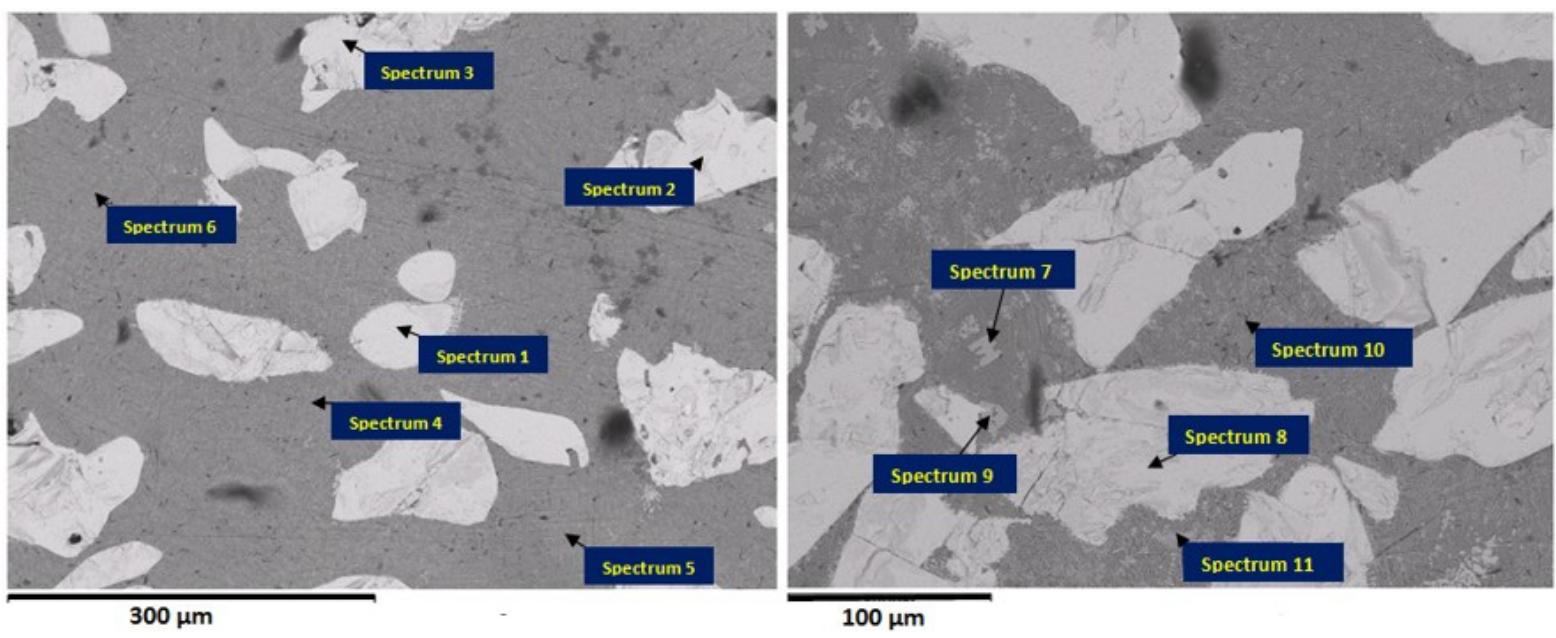

Figure 11. EDS analysis of different phases and particles.

Table 5. Qualitative data (wt\%) of spectra of Figure 11.

\begin{tabular}{lcccccccc}
\hline & Position & C & W & Si & V & Cr & Fe & Ni \\
Spec. 1 & Carbide & 7.26 & 92.74 & - & - & - & - & - \\
Spec. 2 & Carbide & 7.08 & 92.92 & - & - & - & - & - \\
Spec. 3 & Carbide & 7.24 & 92.76 & - & - & - & - & - \\
Spec. 4 & Matrix & 5.04 & 20.71 & 0.23 & 0.39 & 12.71 & 45.72 & 13.15 \\
Spec. 5 & Matrix & 9.49 & 22.89 & - & 0.65 & 17.57 & 38.60 & 9.76 \\
Spec. 6 & Matrix & 5 & 16.31 & 0.77 & 0.35 & 10.70 & 44.34 & 20.38 \\
Spec. 7 & Carbide/Matrix & 5.01 & 50.86 & 3.15 & 0.37 & 13.7 & 9.21 & 17.7 \\
Spec. 8 & Carbide & 5.81 & 81.56 & - & 0.36 & 5.50 & 3.96 & 2.82 \\
Spec. 9 & Carbide/Matrix & 8.90 & 15.05 & 1.55 & 0.31 & 18.90 & 31.30 & 24 \\
Spec. 10 & Matrix & 2.78 & 15.24 & 2.56 & - & 5.61 & 37.33 & 36.48 \\
Spec. 11 & Carbide & 7.82 & 90.83 & - & - & - & - & - \\
\hline
\end{tabular}

\subsection{Hardness profiles}

The hardness value of the base metal was measured around $48 \mathrm{HRC}$. For studying the evolution of hardness through the cross section of the layers, Vickers hardness tests were performed; the results show that the hardness values vary from the top of the hardfaced layer to the base metal according to the different distribution of tungsten carbides in the weld pool. Figure 12 reports the hardness profiles of some selected samples. The maximum hardness 


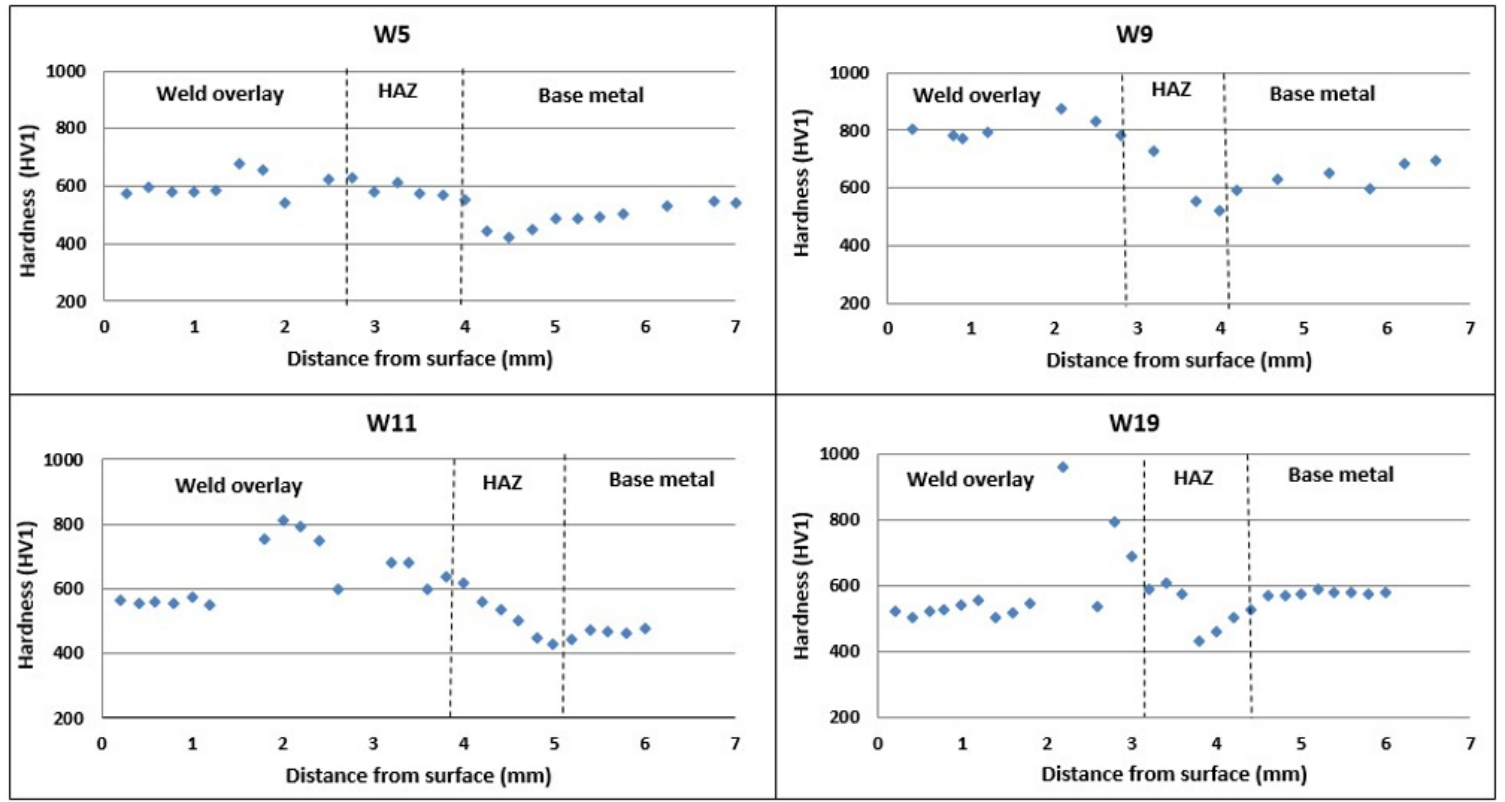

Figure 12. Hardness profiles of some selected samples.

is not at the top of the layer because, as explained before, tungsten carbides are mainly present at the bottom of the layer due to their higher density compared to the matrix. Based on the measured data, for all the samples in the heat-affected zone, hardness decreases from the fusion zone to the base metal, in agreement with the temperature evolution during the hardfacing process. In sample W9, the maximum equal hardness value of $800 \mathrm{HV} 1$ was observed compared to other samples, with hardness of around $600 \mathrm{HV} 1$. The increase in the hardness of sample W9 could be due to the equal distribution of tungsten carbides and to a partial decomposition of tungsten carbides causing a solid solution reinforcement of the matrix.

\subsection{Weld bead measurements and optimum process parameters}

According to Figure 2, the weld characteristics of the weld beads were measured for all the twenty samples. Considering the weld geometry results, the distribution of tungsten carbides and the hardness profiles, the quality of the hardfacing layer of sample W9 can be considered the optimum among all the twenty test layers. The process parameters and the weld bead geometry results for some selected samples (as shown in Figure 6) are specified in Table 6.

Nevertheless, considering the several possible sets of process variables, it is relatively difficult to find the best welding parameters to predict and reach appropriate weld bead characteristics. Based on what is suggested in the literature $[5,10,26,31]$, to reach appropriate weld layer geometry, the value of reinforcement should be the maximum, while the values of penetration and dilution should be the minimum.

Table 6. Parameters and results of some selected samples.

\begin{tabular}{ccccccc}
\hline $\begin{array}{c}\text { Sample } \\
\text { name }\end{array}$ & Current $(\mathbf{A})$ & $\begin{array}{c}\text { Travel speed } \\
(\mathbf{c m} / \mathbf{m i n})\end{array}$ & Preheat $\left({ }^{\circ} \mathbf{C}\right)$ & $\begin{array}{c}\text { Dilution } \\
(\%)\end{array}$ & $\begin{array}{c}\text { Penetration } \\
(\mathbf{m m})\end{array}$ & $\begin{array}{c}\text { Reinforcement } \\
(\mathbf{m m})\end{array}$ \\
W1 & 100 & 70 & 250 & 42.03 & 1.30 & 1.82 \\
W2 & 140 & 70 & 250 & 72.27 & 3.06 & 0.98 \\
W7 & 100 & 100 & 450 & 59.97 & 1.33 & 0.98 \\
W9 & 86.36 & 85 & 350 & 30.52 & 0.69 & 1.43 \\
W19 & 120 & 85 & 350 & 50.10 & 1.22 & 1.15 \\
W20 & 120 & 85 & 350 & 59.17 & 1.60 & 0.79 \\
\hline
\end{tabular}




\section{Conclusions}

In this work a nickel-base powder mixed with tungsten carbide particles was applied by the Plasma Transferred $\operatorname{Arc}$ (PTA) process on the surface of the D2 tool steel. To reach optimum weld bead geometry, a combination of different process parameters (current, travel speed and preheat) were considered and the following conclusions can be made:

- Design of experiments was an effective method to study the effect of process parameters on the weld bead geometry in the PTA process. When the current, penetration and dilution increase, the reinforcement decreases. When the travel speed increases, penetration decreases, maintaining dilution roughly constant with a slight increase. The current was the most important process parameter influencing both the geometry of the weld and the distribution of carbides in the layer;

- The distribution of WC particles in the weld pool was not so homogenous in the weld layer. The carbides mainly accumulated in the lower part of the layer, close to the base metal. According to only one set of parameters their distribution was quite uniform in the layer;

- SEM and EDX analysis of the samples showed that, in addition to blocky WC particles, tungsten was dissolved in the matrix. Complex phases containing tungsten and other carbides former elements were detected in the layers;

- From the microstructural and geometrical data obtained from the analyzed samples, the optimum parameters for hardfacing were actually found as: current $86.36 \mathrm{~A}$, travel speed $85 \mathrm{~cm} / \mathrm{min}$ and preheat $350^{\circ} \mathrm{C}$. With these parameters, the values of dilution, penetration, reinforcement and bead width were $30.52 \%, 0.69 \mathrm{~mm}$, $1.43 \mathrm{~mm}$ and $6.53 \mathrm{~mm}$, respectively. It is very difficult to find the optimum parameters to obtain high quality weld bead geometries, but the authors are currently developing a mathematical model to guide the selection of the best process parameters and more tests will be performed.

\section{Acknowledgements}

Ali Tahaei gratefully acknowledges IUSS 1391 of the University of Ferrara (Unife-ENDIF) for its financial support. Special thanks should also be given to CONACYT for both its financial and experimental support during the internship at Corporación Mexicana de Investigación en Materiales (Comimsa).

\section{References}

[1] Gruzdys E, Meskinis S. Influence of plasma transferred arc process parameters on structure and mechanical properties of wear resistive NiCrBSi-WC/Co coatings. Materials Science. 2011;17(2):140-144. http://dx.doi.org/10.5755/j01.ms.17.2.482.

[2] Díaz VV, Dutra JC, D’Oliveira ASC. Hardfacing by plasma transferred arc process. Croatia: InTech; 2011 [access 26 jan. 2016]. Available from: www.intechopen.com

[3] Deuis RL, Yellup JM, Subramanian C. Metal-Matrix composite coating by PTA surfacing. Composites Science and Technology. 1998;58(2):299-309. http://dx.doi.org/10.1016/S02663538(97)00131-0.

[4] Davis JR, Davis \& Associates. Metals Handbook, Hardfacing, Weld Cladding and Dissimilar Metal Joining. 10th ed. Materials Park: ASM International; 1993. p. 699-823. (ASM Handbook: Welding, Brazing and Soldering, 6).

[5] Balasubramanian V, Lakshminarayanan AK, Varahamoorthy $\mathrm{R}$, Babu S. Application of response surface methodology to prediction of dilution in plasma transferred arc hardfacing of stainless steel on carbon steel. Journal of Iron and Steel Research International. 2009;16(1):44-53. http://dx.doi.org/10.1016/ S1006-706X(09)60009-1.
[6] Siva K, Murugan N. A study on the influence of PTAW process parameters on pitting corrosion resistance of nickel based overlays. Procedia Engineering. 2013;64:1147-1156. http:// dx.doi.org/10.1016/j.proeng.2013.09.193.

[7] Bourithis E, Tazedakis A, Papadimitriou G. A study on the surface treatment of "Calmax" tool steel by a plasma transferred arc (PTA) process. Journal of Materials Processing Technology. 2002;128(1-3):169-177. http://dx.doi.org/10.1016/S09240136(02)00447-8.

[8] Sudha C, Shankar P, Rao RVS, Thirumurugesan R, Vijayalakshmi $M$, Raj B. Microchemical and microstructural studies in a PTA weld overlay of $\mathrm{Ni}-\mathrm{Cr}-\mathrm{Si}-\mathrm{B}$ alloy on AISI $304 \mathrm{~L}$ stainless steel. Surface and Coatings Technology. 2008;202(10):2103-2112. http://dx.doi.org/10.1016/j.surfcoat.2007.08.063.

[9] Kim HJ, Yoon BH, Lee $\mathrm{CH}$. Wear performance of the Fe-based alloy coatings produced by plasma transferred arc weldsurfacing process. Wear. 2002;249(10-11):846-852. http:// dx.doi.org/10.1016/s0043-1648(01)00683-4.

[10] Nouri M, Abdollah-Zadeh A, Malek F. Effect of welding parameters on dilution and weld bead geometry in cladding. Journal of Materials Science and Technology. 2007;23(6):817-822. 
[11] Chatterjee S, Pal TK. Wear behaviour of hardfacing deposits on cast iron. Wear. 2003;255(1-6):417-425. http://dx.doi.org/10.1016/ S0043-1648(03)00101-7.

[12] Kesavan D, Kamaraj M. The microstructure and high temperature wear performance of a nickel base hardfaced coating. Surface and Coatings Technology. 2010;204(24):4034-4043. http://dx.doi. org/10.1016/j.surfcoat.2010.05.022.

[13] Ramachandran CS, Balasubramanian V, Varahamoorthy R. Evaluation of dry sliding wear behaviour of plasma transferred arc hardfaced stainless steel. International Journal of Iron and Steel Research. 2009;16(4):49-54. http://dx.doi.org/10.1016/ S1006-706X(09)60060-1.

[14] Zikin A, Hussainova I, Katsich C, Badisch E, Tomastik C. Advanced chromium carbide-based hardfacing. Surface and Coatings Technology. 2012;206(19-20):4270-4278. http://dx.doi.org/10.1016/j. surfcoat.2012.04.039.

[15] Yaedu AE, D'Oliveira ASCM. Cobalt based alloy PTA hardfacing on different substrate steels. Materials Science and Technology. 2005;21(4):459-466. http://dx.doi.org/10.1179/174328 $413 \times 13789824293380$.

[16] Balamurugan S, Murugan N. Design of experiment and optimization of plasma transferred arc hardfacing on structural steel with Titanium Carbide. Research Journal of Applied Sciences, Engineering and Technology. 2014;7(11):2362-2370.

[17] Conde A, Zubiri F, Damborenea YJ. Cladding of Ni-Cr-B-Si coatings with a high power diode laser. Materials Science and Engineering A. 2002;334(1-2):233-238. http://dx.doi.org/10.1016/S09215093(01)01808-1.

[18] Tobar MJ, Álvarez C, Amado JM, Rodríguez G, Yáñez A. Morphology and characterization of laser clad composite NiCrBSi-WC coatings on stainless steel. Surface and Coatings Technology. 2006;200(2223):6313-6317. http://dx.doi.org/10.1016/j.surfcoat.2005.11.093.

[19] McGlone JC. Weld bead geometry prediction: a review. Metal Construction. 1982;14:378-384.

[20] García-Vázquez F, Aguirre A, Arizmendi-Morquecho A, HernándezGarcía HM, Santiago-Bautista L, Acevedo J, et al. Analysis of weld bead parameters of overlay deposited on D2 steel components by plasma transferred arc (PTA) process. Materials Science Forum. 2013;755:39-45. http://dx.doi.org/10.4028/www.scientific.net/ MSF.755.39.
[21] Kim I-S, Son J-S, Jeung Y-J. Control and optimization of bead width for multi-pass welding in robotic arc welding processes. Austrian Welding Journal. 2001;46:43-46.

[22] Ming Q, Lim LC, Chen ZD. Laser cladding of nickel-based hardfacing alloys. Surface and Coatings Technology. 1998;106(2-3):174-182. http://dx.doi.org/10.1016/S0257-8972(98)00524-6.

[23] Lim LC, Ming Q, Chen ZC. Microstructures of laser-clad nickelbased hardfacing alloys. Surface and Coatings Technology. 1998;106(2-3):183-192. http://dx.doi.org/10.1016/S02578972(98)00525-8.

[24] Palani PK, Murugan N. Optimization of weld bead geometry for stainless steel claddings deposited by FCAW. Journal of Materials Processing Technology. 2007;190(1-3):291-299. http://dx.doi. org/10.1016/j.jmatprotec.2007.02.035.

[25] Palani PK, Murugan N. Development of mathematical models for prediction of weld bead geometry in cladding by flux cored arc welding. International Journal of Advanced Manufacturing Technology. 2006;30(7-8):669-676. http://dx.doi.org/10.1007/ s00170-005-0101-2.

[26] Siva K, Murugan N, Raghupathy VP. Modelling, analysis and optimization of weld bead parameters of nickel based overlay deposited by plasma transferred arc surfacing. Computational Materials Science and Surface Engineering. 2009;1(3):174-182.

[27] Chandler HE. Heat treater's guide: practices and procedures for irons and steels. Materials Park: ASM International; 1994.

[28] Roberts G. Tool steels. 5th ed. Materials Park: ASM International; 1998.

[29] Fu JW, Yang YS, Guo JJ. Microstructure selection of $\mathrm{Fe}-\mathrm{Cr}-\mathrm{Ni}$ alloy during directional solidification. International Journal of Cast Metals Research. 2010;23(2):119-123. http://dx.doi.org/ 10.1179/136404609X12572514498892.

[30] Li Q, Lei TC, Chen WZ. Microstructural characterization of WC reinforced $\mathrm{Ni}-\mathrm{Cr}-\mathrm{B}-\mathrm{Si}-\mathrm{C}$ composite coatings. Surface and Coatings Technology. 1999;114(2-3):285-291. http://dx.doi. org/10.1016/S0257-8972(99)00056-0.

[31] Bhaskarananda Dasgupta E, Mukherjee S. Optimization of weld bead parameters of nickel based overlay deposited by plasma transferred arc surfacing. International Journal of Modern Engineering Research. 2013;3(3):1330-1335. 